\title{
Synthesis and Release of Glucagon by Human Salivary Glands
}

\author{
Ana Pérez-Castillo and E. Blázquez \\ Instituto "G. Marañón”, C.S.I.C., Madrid, Spain
}

Summary. Pieces of human salivary glands were homogenised with acid-ethanol or acid-saline solutions immediately after surgical removal. With both extraction procedures the immunoreactive glucagon (IRG) content in the submaxillary glands was greater than in parotid glands as determined with a C-terminal reactive glucagon antiserum (30K). Higher amounts of IRG were determined in acid-saline extracts of submaxillary (18.5 \pm 2.5 vs $8.9 \pm 1.2 \mathrm{ng} / \mathrm{g}$ wet weight) and parotid ( $3.5 \pm 0.3$ vs $2.9 \pm 0.3 \mathrm{ng} / \mathrm{g}$ wet weight) glands compared with concentrations obtained with acid-ethanol extracts. IRG material extracted with the latter procedure has similar immunological and biological characteristics as pancreatic glucagon. After fractionation of the acidethanol extracts on P-30 columns or gel electrophoresis, an immunoreactive peak of 3500 daltons was always obtained. Arginine, ephinephrine and low glucose concentrations stimulated glucagon release from both salivary glands. Active glucagon biosynthesis by these glands was established by the incorporation of ${ }^{3} \mathrm{H}$-L-tryptophan into a 3500 daltons polypeptide with specific immune reaction with $30 \mathrm{~K}$ antiserum. These findings indicate that human salivary glands represent a source of extrapancreatic glucagon in man and may therefore contribute to the circulating levels of this hormone.

Key words: Human salivary glands, glucagon-chemical characterisation, biological activity, glucagon synthesis, glucagon release.

In recent years there has been considerable interest in the extrapancreatic production of glucagon. A polypeptide with the same immunological, phy- sicochemical and biological properties as pancreatic glucagon has been purified from the gastrointestinal mucosa of the dog $[1,2]$. Also, cells with immunocytochemical and ultrastructural characteristics similar to pancreatic A cells have been identified in the gastrointestinal mucosa in humans [3, 4] and in laboratory animals $[5,6]$. These A cells release glucagon in response to specific stimuli, especially in pancreatectomised and alloxan diabetic dogs [7-9]. The existence of immunoreactive glucagon type material in kidneys and salivary glands has now also been reported by several authors [10-12]. In human and rat salivary glands, a polypeptide with biological and secretory properties close to those of the pancreatic glucagon but with a greater molecular weight has been identified $[13,14]$. The question remains however as to whether the presence of this immunoreactive component indicates active synthesis and storage or merely selective trapping of circulating glucagon by the salivary glands.

The present study was undertaken to determine the nature of IRG from human salivary glands using immunological, physicochemical and biological criteria. In addition, we studied the biosynthetic and secretory patterns of glucagon in an attempt to define the responsiveness of human salivary glands glucagon secretion to physiological stimuli.

\section{Material and Methods}

\section{Processing of Human Salivary Glands}

Pieces of human submaxillary and/or parotid glands were obtained under general anaesthesia from patients being operated upon because of lithiasis or tumours in these organs. Non-affected glandular tissue surrounding the diseased tissue was selected for study. The reported studies were performed in accordance with the principles of the Declaration of Helsinki. 
Table 1. Immunoreactive glucagon and GLI content of human submaxillary and parotid glands. The hormones were measured in acid-ethanol extracts as described in Methods. Results are presented as mean \pm SEM

\begin{tabular}{llc}
\hline Salivary glands & $\begin{array}{l}\text { Glucagon content } \\
\text { ng/g wet weight }\end{array}$ & $\begin{array}{l}\text { GLI content } \\
\mathrm{ng} / \mathrm{g} \text { wet weight }\end{array}$ \\
\hline Submaxillary $\mathrm{n}=7$ & $8.9 \pm 1.2$ & $10.2 \pm 0.8$ \\
Parotid $\mathrm{n}=3$ & $2.9 \pm 1.3$ & $3.1 \pm 0.9$ \\
\hline
\end{tabular}

Table 2. Immunoreactive glucagon content of human salivary glands as measured in acid-ethanol and acid-saline extracts. The hormone was determined as described in Methods. Results are presented as mean $\pm \mathrm{SEM}$

\begin{tabular}{llr}
\hline Salivary glands & \multicolumn{2}{l}{$\begin{array}{l}\text { Glucagon content } \\
\mathrm{ng} / \mathrm{g} \text { wet tissue }\end{array}$} \\
\cline { 2 - 3 } & Acid-ethanol & Acid-saline \\
\hline Submaxillary $\mathrm{n}=7$ & $8.9 \pm 1.2$ & $18.5 \pm 2.5$ \\
Parotid $\mathrm{n}=3$ & $2.9 \pm 1.3$ & $3.5 \pm 0.3$ \\
\hline
\end{tabular}

\section{Hormonal Extraction and Measurement of Glucagon and GLI}

Immediately after surgical removal, small pieces of human submaxillary and parotid glands were weighed and homogenised in an acid-alcohol solution (ethanol, distilled water, $\mathrm{HCl}$; 75:23.2:1.8; $\mathrm{v} / \mathrm{v}, 10 \mathrm{ml}$ per $\mathrm{g}$ tissue) or in $0.154 \mathrm{~mol} / \mathrm{l} \mathrm{NaCl}$ acidified with $\mathrm{HCl}$ to $\mathrm{pH} 2.8$. Specimens of liver, spleen and lung from rat were used as control tissues. The extraction procedure was essentially that described by Kenny [15]. The homogenates were kept at $4^{\circ} \mathrm{C}$ overnight, and the precipitates obtained after centrifugation $(1500 \mathrm{xg}$ for $15 \mathrm{~min})$ were extracted again for $4 \mathrm{~h}$ at $4^{\circ} \mathrm{C}$. The mixed supernatants were lyophilised and subsequently dissolved in the assay buffer. Aliquots of these solutions were used for column chromatography as well as for biological activity studies. Tracer amounts of the radioactive hormone were added at the beginning of the tissue extraction procedure and the percentage of hormone degradation was evaluated after trichloroacetic acid precipitation. Glucagon and GLI were measured by radioimmunoassay. Glucagon immunoreactivity [16] was determined with a C-terminal reactive antiglucagon serum $(30 \mathrm{~K})$ generously donated by Dr. R. Unger. GLI was measured with a N-terminal reactive antiglucagon serum (AG-10) donated by Dr. P. P. Fòa.

\section{Gel Filtration Column Chromatography}

Aliquots of the acid-ethanol extracts $(800-9000 \mathrm{pg}$ of IRG) obtained as described above were further purified by Bio-Gel P-30 filtration after equilibration of the columns with $0.2 \mathrm{~mol} / 1$ glycine buffer $\mathrm{pH} 8.6$, supplemented with $0.25 \mathrm{~g} / 100 \mathrm{ml}$ bovine serum albumin (BSA) and $1 \%(\mathrm{v} / \mathrm{v})$ sheep serum. Routine column calibration was with blue dextran, ${ }^{125} \mathrm{~T}$-insulin and ${ }^{125} \mathrm{I}$-glucagon. The immunoreactivities on the eluates were assayed with $30 \mathrm{~K}$ antibody.

\section{Polyacrylamide Disc Gel Electrophoresis}

Disc electrophoresis [17] was carried out in $7 \%$ gel containing $4 \mathrm{~mol} / 1$ urea at $\mathrm{pH} \mathrm{8.7.} \mathrm{Crystalline} \mathrm{glucagon} \mathrm{(Novo} \mathrm{Laboratories,}$ Copenhagen, Denmark) was electrophoresed simultaneously in separate gel and stained with Coomassie Blue [18]. Unstained gels containing the crystalline hormone or the experimental samples were cut into $2 \mathrm{~mm}$ sections. Each section was eluted with $0.2 \mathrm{ml}$ of immunoassay diluent. The eluates from each section were assayed for IRG with antiserum $30 \mathrm{~K}$.

\section{Receptor Binding Studies}

The biological activity of extrapancreatic glucagon was tested by measuring the ability of partially purified glucagon from salivary glands to displace monoiodinated ${ }^{125} \mathrm{I}$-labelled glucagon from isolated rat liver membranes.

Liver membranes were purified by Neville's procedure [19]. Their 5'nucleotidase activity [20] was used as an index of membrane purity. Monoiodinated ${ }^{125} \mathrm{I}$-labelled glucagon $(380-500 \mu \mathrm{Ci} /$ $\mu \mathrm{g})$ was obtained according to the procedure of Nottey and Rosselin [21]. Membrane protein was determined by the method of Lowry et al. [22]. Liver membranes $(50-100 \mu \mathrm{g}$ protein) were incubated in $0.5 \mathrm{ml}$ of Krebs-Ringer phosphate buffer, $\mathrm{pH} 7.5$, containing BSA $(1 \mathrm{~g} / 100 \mathrm{ml})$ and partially purified glucagon from salivary glands or crystalline glucagon $(20-5000 \mathrm{pg} / \mathrm{ml})$. After incubation at $20^{\circ} \mathrm{C}$ for $30 \mathrm{~min}, 80 \mathrm{pg}$ of monoiodinated ${ }^{125} \mathrm{I}$-labelled glucagon was added and the resulting mixture was incubated at $20^{\circ} \mathrm{C}$ for $15 \mathrm{~min}$. The samples were then rapidly diluted with $1 \mathrm{ml}$ of ice cold $1 \mathrm{~g} / 100 \mathrm{ml} \mathrm{BSA}$ in Krebs-Ringer phosphate, $\mathrm{pH} 7.5$, and immediately filtered on oxoid filters which had been presoaked in $10 \mathrm{~g} / 100 \mathrm{ml} \mathrm{BSA}$ for $1 \mathrm{~h}$. Radioactivity was determined in a well-type scintillation counter.

\section{Synthesis and Release of Extrapancreatic Glucagon}

Biosynthesis and release of extrapancreatic glucagon were studied with isolated cells obtained from human salivary glands and rat liver. Glandular tissue was minced with scissors and incubated with Krebs-Ringer bicarbonate buffer, $\mathrm{pH} 7.4$, and $1 \mathrm{mg} / 100 \mathrm{mg}$ wet tissue of collagenase, type I (Sigma Chem. Comp., St. Louis, U.S.A.) during $5 \mathrm{~min}$ at $37^{\circ} \mathrm{C}$. The digested salivary glands were filtered and washed three times with $50 \mathrm{ml}$ of Krebs-Ringer bicar-

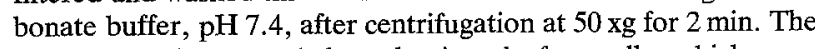
final suspension revealed predominantly free cells, which were $95 \%$ viable as judged by their ability to exclude $0.5 \%$ trypan blue in the absence of albumin. As controls for the biosynthesis and release of glucagon by cells of salivary glands, isolated hepatocytes prepared from overnight fasted rats were used. Animals were anaesthetised with ether, the abdomen opened through a wide incision and the portal vein exposed and cannulated. The liver was then perfused with $120 \mathrm{ml}$ of calcium and magnesium-free KrebsRinger bicarbonate buffer, pH 7.4 for $4 \mathrm{~min}$. Another $150 \mathrm{ml}$ of perfusion media with $40 \mathrm{mg}$ of collagenase, type I (Sigma Chemical Co., St. Louis, U.S.A.), were infused into the liver for $5 \mathrm{~min}$. The digested liver was filtered, and the cells spun down at $50 \mathrm{xg}$ for $2 \mathrm{~min}$. The suspension revealed predominantly free hepatocytes, which were $85 \%$ viable as judged by their ability to exclude $0.5 \%$ trypan blue in the absence of albumin. All procedures with isolated cells were carried out in plastic laboratory ware. Subsequently, isolated cells $\left(1 \times 10^{5}\right.$ cells $)$ were incubated with $1 \mathrm{ml}$ of Krebs-Ringer bicarbonate, $\mathrm{pH} 7.4$, enriched with BSA $(1 \mathrm{~g} / 100 \mathrm{ml})$ and glucose $(30,100$ or $300 \mathrm{mg} / 100 \mathrm{ml})$ or arginine $(5 \mathrm{mmol} / \mathrm{l})$, porcine monocomponent insulin $(5 \mu \mathrm{g}$; Novo Laboratories, Copenhagen, Denmark) or norepinephrine (5 $\mu \mathrm{g}$; Sigma Chemical Co., St. Louis, U.S.A.) in an atmosphere of $95 \%$ $\mathrm{O}_{2}$ and $5 \% \mathrm{CO}_{2}$ at $37^{\circ} \mathrm{C}$, using a metabolic incubator. After $2 \mathrm{~h}$ incubation, isolated cells were removed and the concentration of glucagon in the buffer was determined by radioimmunoassay using the $30 \mathrm{~K}$ antiserum.

The biosynthesis of extrapancreatic glucagon was studied with isolated cells $\left(4 \times 10^{5}\right)$, obtained as detailed above. Samples were incubated at $37^{\circ} \mathrm{C}$ for $4 \mathrm{~h}$ in $1 \mathrm{ml}$ of Krebs-Ringer bicarbonate 


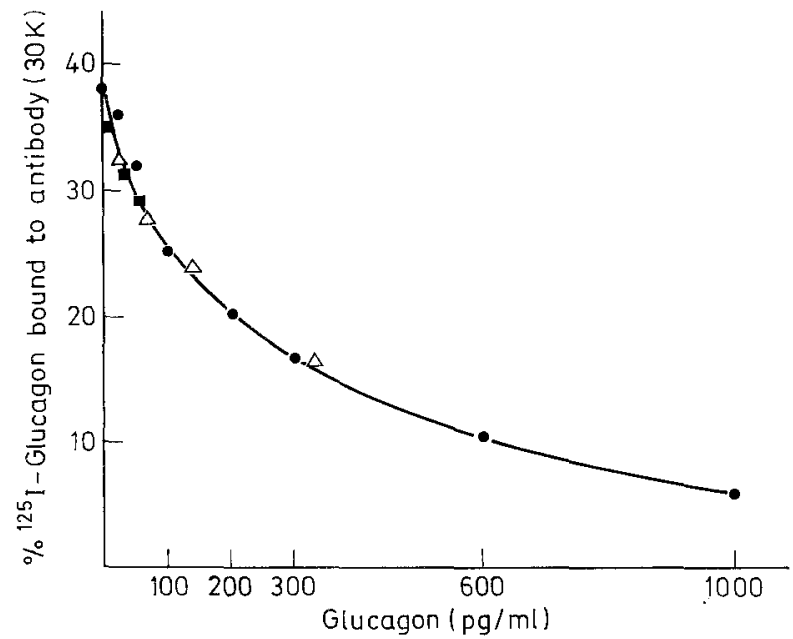

Fig. 1. Immunoassay of highly purified porcine crystalline glucagon standard and acid-ethanol extracts from human submaxillary and parotid glands. The assays were carried out with $30 \mathrm{~K}$ antiserum. Concentration of tissue IRG was calculated from the dilution of acid-ethanol extracts. - Crystalline glucagon, $\triangle-\triangle$ Submaxillary gland extract, $\square-\mathbf{m}$ Parotid gland extract

buffer, pH 7.4 , containing BSA $(1 \mathrm{~g} / 100 \mathrm{ml})$, glucose $(100 \mathrm{mg} / 100 \mathrm{ml})$ and $10 \mu \mathrm{Ci}{ }^{3} \mathrm{H}$-L-tryptophan $(6 \mathrm{Ci} / \mathrm{mmol}$; The Radiochemical Centre, Amersham, England) in an atmosphere of $95 \% \mathrm{O}_{2}$ and $5 \% \mathrm{CO}_{2}$. At the end of the incubation period, $1 \mathrm{mg}$ of unlabelled tryptophan, and in some cases crystalline glucagon $(0.29 \mathrm{mmol} / \mathrm{l}, 1 \mathrm{mg})$ was added, and the cells were homogenised in their own incubation medium. Homogenates were treated according to the Kenny procedure [15] and their hormonal components were further purified by chromatography in Bio-Gel P-30 columns $(1 \times 60 \mathrm{~cm})$, precalibrated as described above. The columns were eluted with $2 \mathrm{~mol} / \mathrm{l}$ acetic acid or $0.2 \mathrm{~mol} / \mathrm{l}$ glycine buffer, containing BSA $(0.25 \mathrm{~g} / 100 \mathrm{ml})$, sheep serum $(1 \%, \mathrm{v} / \mathrm{v}), \mathrm{pH} 8.6$, and $1 \mathrm{ml}$ fractions were collected. Aliquots of the eluates were taken for measurements of radioactivity and $30 \mathrm{~K}$ immunoreactivity. For this purpose, aliquots of the eluates were preincubated for $1 \mathrm{~h}$ at $37^{\circ} \mathrm{C}$ with $30 \mathrm{~K}$ antiserum and subsequently for $48 \mathrm{~h}$ at $4^{\circ}$ in the presence of a goat anti-rabbit gamma globulin (1:240 final dilution), generously donated by Dr. E. Montoya. The samples were spun for $15 \mathrm{~min}$ at $1500 \mathrm{xg}$ and the precipitate solubilised with $0.01 \mathrm{~mol} / \mathrm{l}$ $\mathrm{NaOH}$, mixed with $10 \mathrm{ml}$ of scintillation fluid and counted in a well-type counter.

\section{Calculations}

Results are presented as mean \pm SEM. Comparisons were made using the Student $t$ test.

\section{Results}

\section{Glucagon and GLI Content of Human Submaxillary and Parotid Glands}

The glucagon content, as determined with $30 \mathrm{~K}$ antiserum, was $8.9 \pm 1.2 \mathrm{ng} / \mathrm{g}$ wet weight in submaxillary glands and $2.9 \pm 1.3 \mathrm{ng} / \mathrm{g}$ wet weight in parotid glands (Table 1). When the AG-10 antiserum was

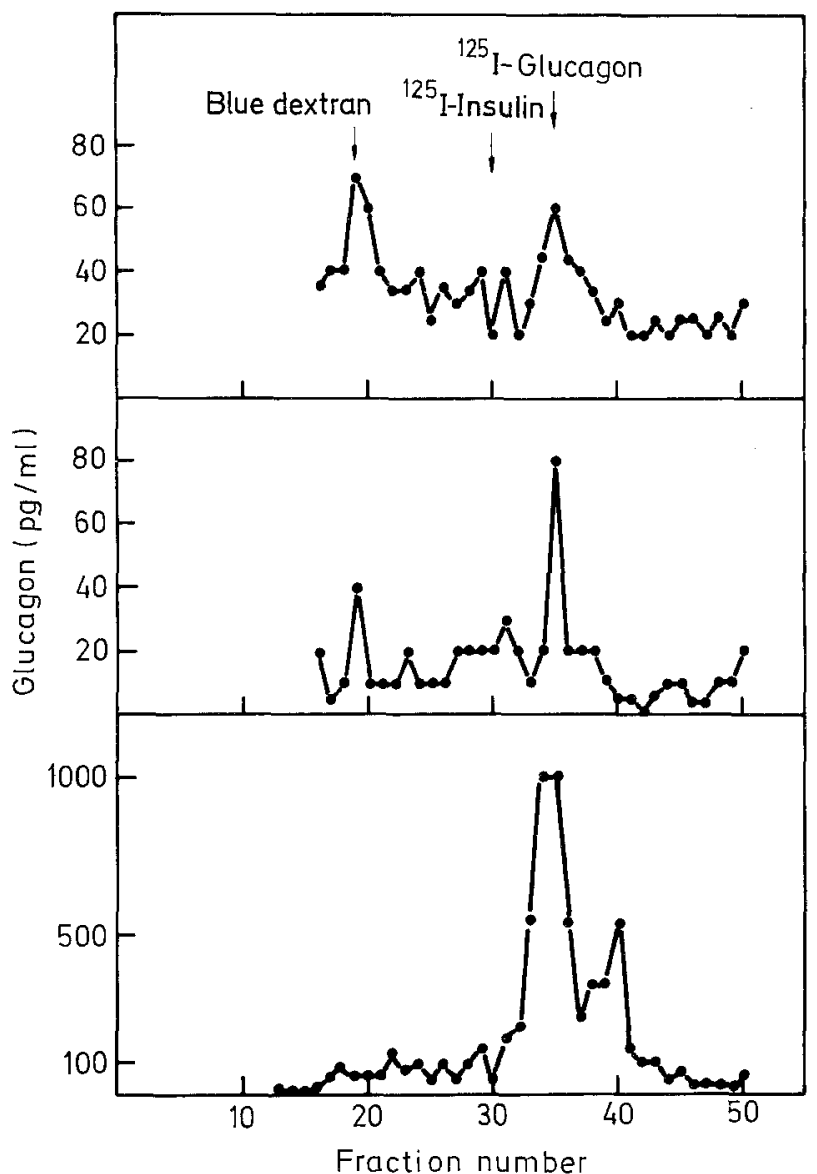

Fig. 2. Gel filtration of acid-ethanol extracts of three human submaxillary glands. The material applied $(800-9000 \mathrm{pg}$ of IRG) to columns $(1 \mathrm{~cm} \times 60 \mathrm{~cm})$ of Bio-Gel P-30 (100-200 mesh) was equilibrated with $0.2 \mathrm{~mol} / 1$ glycine buffer, $\mathrm{pH} 8.6$, plus $0.25 \mathrm{~g} / 100 \mathrm{ml} \mathrm{BSA} ; 1 \mathrm{ml}$ fractions were collected; aliquots were assayed for IRG with $30 \mathrm{~K}$ antiserum

used in the radioimmunoassay, the GLI content was $10.2 \pm 0.8 \mathrm{ng} / \mathrm{g}$ wet weight in the submaxillary glands and $3.1 \pm 0.9 \mathrm{ng} / \mathrm{g}$ wet weight in the parotid glands. The values for GLI and glucagon did not differ significantly. However, marked differences in glucagon content (as determined with $30 \mathrm{~K}$ antiserum) were noted when a different method of extraction was used. Thus the glucagon concentrations in the salivary glands were greater with an acid-saline than with an acid-ethanol extraction procedure (Table 2).

The percentage of glucagon degradation during the acid-ethanol hormone extraction was minimal, even in the absence of aprotinin $(1000 \mathrm{KIU} / \mathrm{ml})$. However with the acid-saline extraction procedure there was $67.3 \%$ glucagon degradation by submaxillary glands and this was still to $48 \%$ with aprotinin present.

As controls, pieces of liver, spleen and lungs from rat were extracted and no IRG was detected. 


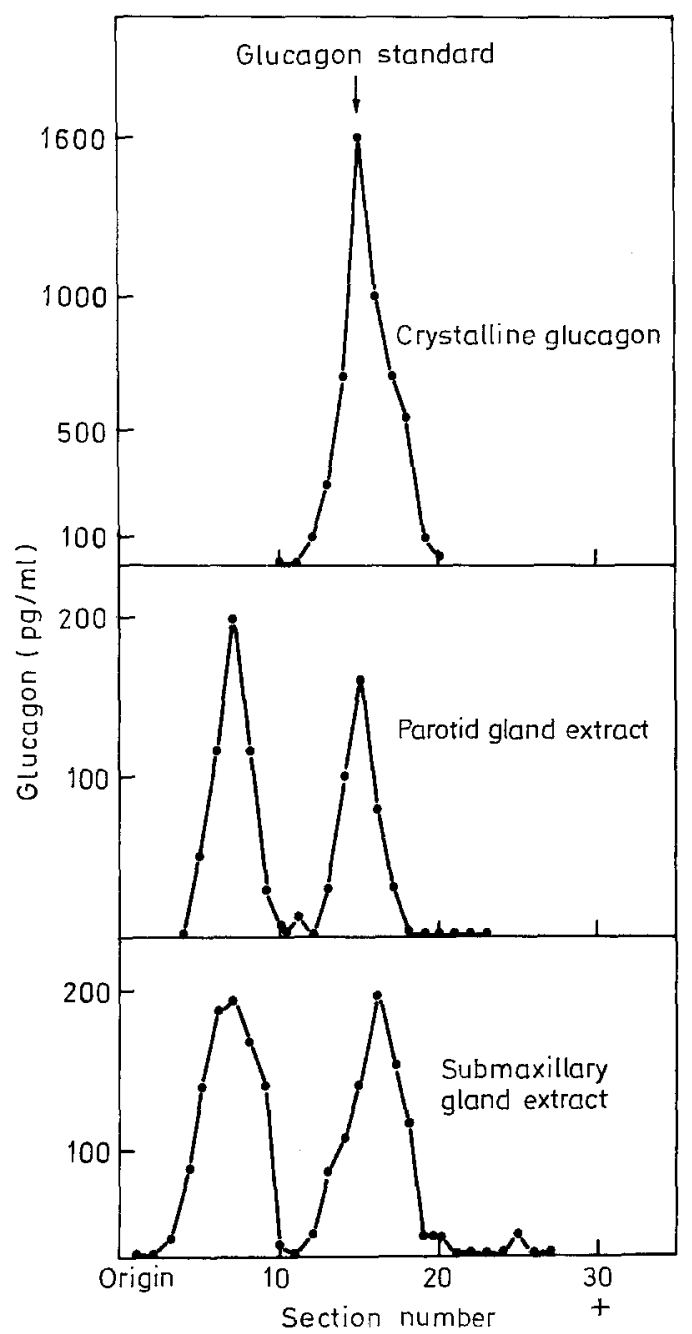

Fig. 3. Polyacrylamide gel electrophoresis of crystalline porcine glucagon and acid-ethanol extracts $(1500-2500 \mathrm{pg}$ of IRG) of human submaxillary and parotid glands. Electrophoresis was carried out in a $7 \%$ gel containing $4 \mathrm{~mol} / 1$ urea at $\mathrm{pH} 8.7$. Standard porcine crystalline glucagon was electrophoresed in parallel in a separate gel tube and stained. The unstained gel containing the samples was cut into $2 \mathrm{~mm}$ sections. The eluates were assayed for IRG antiserum

Partial Characterisation of Immunoreactive Glucagon from Human Salivary Glands

Figure 1 shows that the immunoassay dilution curves of the acid-ethanol extracts of human salivary glands were essentially identical to the dilution curves of highly purified crystalline porcine glucagon. Thus a glucagon immunoassay using antiserum $30 \mathrm{~K}$ could not distinguish between pancreatic glucagon standard and immunoreactive glucagon from the salivary glands.
A. Pérez-Castillo and E. Blázquez: Glucagon and Human Salivary Glands

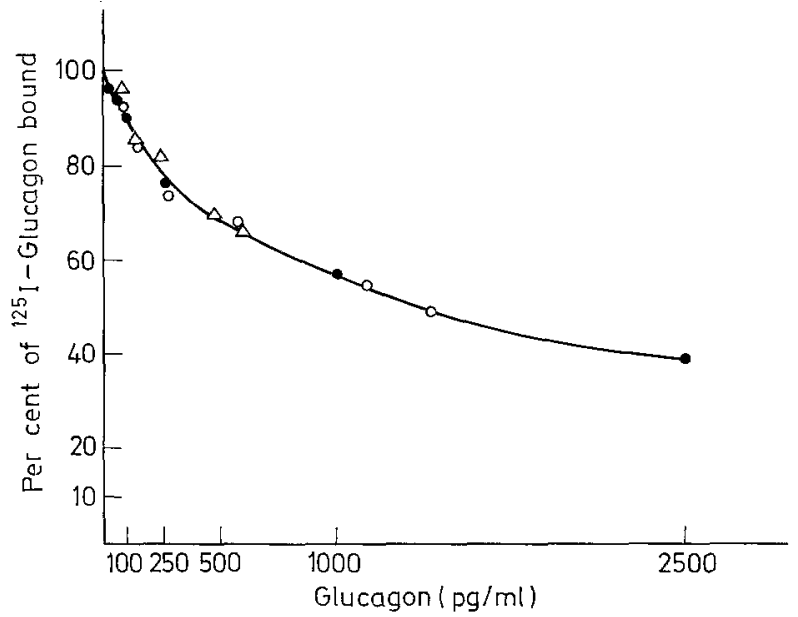

Fig. 4. Competition between ${ }^{125} \mathrm{I}$-glucagon ( $80 \mathrm{pg}$ ) and crystalline porcine glucagon or glucagon present in acid-ethanol extracts from human submaxillary and parotid glands, for binding to rat liver membranes. Binding of labelled glucagon in the absence of unlabelled IRG was taken as $100 \%$. The non-specific binding was less than $5 \%$ of total binding. Crystalline glucagon, $\bigcirc-\bigcirc$ Submaxillary gland, $\triangle-\triangle$ Parotid gland

\section{Gel Filtration Column Chromatography}

The chromatographic profiles of three human salivary gland acid-ethanol extracts are shown in Figure 2. Different peaks of immunoreactivity were detected in the three extracts, but one peak in particular eluted with the ${ }^{125}$ I-glucagon marker in all cases.

\section{Polyacrylamide Disc Gel Electrophoresis}

Disc electrophoresis of the highly purified crystalline porcine glucagon in $4 \mathrm{~mol} / \mathrm{l}$ urea resolved it into one main peak of immunoreactivity (Fig. 3). This component was localised in the same position as the main band stained with Coomassie Blue. A similar pattern of immunoreactivity distribution was obtained with submaxillary or parotid gland acid-ethanol extracts, showing an identity between crystalline glucagon and the hormone present in the tissue extracts. In addition, a slower-moving immunoreactive component was observed with extracts of the salivary glands.

\section{Biological Activity of Human Salivary Glands Glucagon}

In order to compare the biological activity of glucagon present in the submaxillary and parotid gland acid-ethanol extracts to that of highly purified crystalline porcine glucagon, a receptor assay system was used. The activity of $5^{\prime}$ nucleotidase increases from $0.95 \mu \mathrm{mol} 5^{\prime}$ AMP hydrolysed $/ \mathrm{mg}$ protein $/ \mathrm{h}$ in the original liver homogenate to $6.98 \mu \mathrm{mol} 5^{\prime}$ AMP hy- 


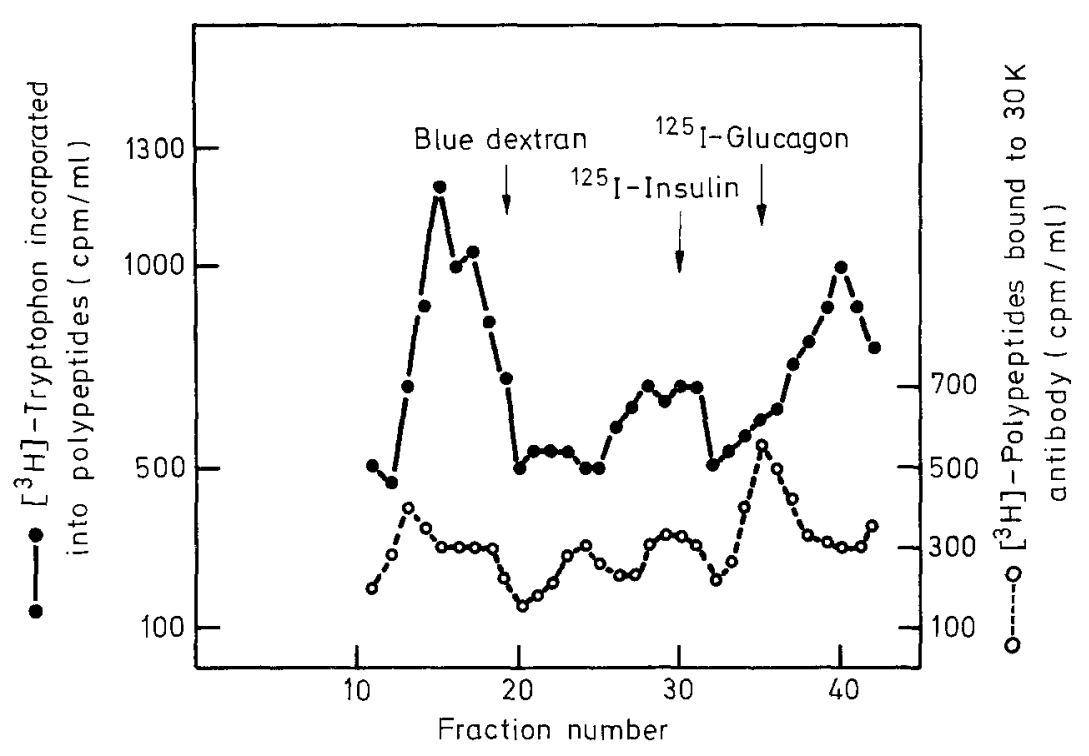

Fig. 5. Elution profile from Bio-Gel P-30 of. proteins from human submaxillary gland labelled with ${ }^{3} \mathrm{H}$-L-tryptophan (solid lines). Aliquots of the eluates were incubated with $30 \mathrm{~K}$ antiserum. The radioactivity bound to the glucagon antibody is represented by the broken line drolysed/mg protein/h in the purified liver membranes.

As shown in Figure 4 the ability of crystalline porcine glucagon to displace mono ${ }^{125} \mathrm{I}$-glucagon from purified liver membranes was similar to that of the glucagon extracted from the salivary glands.

\section{Synthesis and Release of Glucagon from Human Salivary Glands}

Isolated cells from human salivary glands and rat liver were incubated in vitro with ${ }^{3} \mathrm{H}$-L-tryptophan. After the incubation period the acid-ethanol extracts of these cells were further purified in Bio-Gel P-30 columns. After chromatography fractionation of the salivary gland extracts, ${ }^{3} \mathrm{H}$-L-tryptophan was found in various peaks of radioactivity (Fig. 5), especially that which eluted with the ${ }^{125}$ I-glucagon marker. Aliquots of the eluates were incubated with $30 \mathrm{~K}$ antiserum and the radioactivity bound to the glucagon antibody was distributed in several peaks, one of which was localised in the same position as ${ }^{125} \mathrm{I}$-glucagon. Conversely, we were not able to detect any radioactivity bound to the $30 \mathrm{~K}$ antiserum in the eluates of hepatocyte extracts.

Isolated cells from salivary glands and rat liver were incubated in vitro with different stimulants and inhibitors of pancreatic glucagon secretion. Glucagon release by salivary gland cells (Table 3 ) was stimulated by $5 \mathrm{mmol} / \mathrm{l}$ arginine, norepinephrine $(5 \mu \mathrm{g} / \mathrm{ml})$ and low glucose concentrations. Porcine monocomponent insulin $(5 \mu \mathrm{g} / \mathrm{ml})$ did not modify basal secretion of glucagon. On the other hand, no glucagon release from isolated hepatocytes could be found under similar conditions.
Table 3. Glucagon release by isolated submaxillary and parotid glands cells. Isolated cells were incubated with $1 \mathrm{ml}$ of KrebsRinger bicarbonate buffer, $\mathrm{pH} 7.4$, enriched with BSA $(1 \mathrm{~g} / 100 \mathrm{ml})$ and glucose $(1.6,5.5$ or $16.6 \mathrm{mmol} / \mathrm{l})$ or arginine $(5 \mathrm{mmol} / \mathrm{l})$, insulin $(0.8 \mu \mathrm{mol} / \mathrm{l})$ or norepinephrine $(20 \mu \mathrm{mol} / \mathrm{l})$, in an atmosphere of $95 \% \mathrm{O}_{2}$ and $5 \% \mathrm{CO}_{2}$ at $37^{\circ} \mathrm{C}$. After $2 \mathrm{~h}$ incubation, cells were removed and the concentration of glucagon in the buffer was determined using the $30 \mathrm{~K}$ antiserum. As basal release of glucagon was considered that obtained in the presence of $5.5 \mathrm{mmol} / 1$ glucose. Results are presented as mean $\pm \mathrm{SEM}$

\begin{tabular}{lll}
\hline Stimulus & \multicolumn{2}{l}{ Glucagon release } \\
\cline { 2 - 3 } & $\begin{array}{l}\text { Submaxillary } \\
\text { cells }(\mathrm{n}=7) \\
\mathrm{pg} / 5 \times 10^{5} \\
\text { cells } / 2 \mathrm{~h}\end{array}$ & $\begin{array}{l}\text { Parotid cells } \\
(\mathrm{n}=3) \\
\mathrm{pg} / 5 \times 10^{5} \\
\text { cells } / 2 \mathrm{~h}\end{array}$ \\
\hline Glucose $(1.6 \mathrm{mmol} / \mathrm{l})$ & $725 \pm 35$ & $725 \pm 60$ \\
Glucose $(5.5 \mathrm{mmol} / \mathrm{l})$ & $585 \pm 70$ & $550 \pm 155$ \\
Glucose $(16.6 \mathrm{mmol} / \mathrm{l})$ & $445 \pm 90$ & $440 \pm 15$ \\
Insulin $(0.8 \mu \mathrm{mol} / 1)$ & $495 \pm 80$ & $500 \pm 145$ \\
Arginine $(5 \mathrm{mmol} / \mathrm{l})$ & $920 \pm 185$ & $900 \pm 285$ \\
Norepinephrine $(20 \mu \mathrm{mol} / \mathrm{l})$ & $795 \pm 120$ & $615 \pm 190$ \\
\hline
\end{tabular}

\section{Discussion}

Silverman and Dunbar [11] first described the existence of immunoreactive glucagon in the rat salivary glands. Subsequently several authors have reported the presence of this immunological component in the submaxillary glands of humans and different laboratory animals [12-14], which differs from pancreatic or gastrointestinal glucagon because of its insolubility in alcohol and greater molecular weight. Also, a more prolonged hyperglycaemic effect in vivo and a different competition pattern with ${ }^{125} \mathrm{I}$-glucagon in liver 
membranes seems to distinguish this IRG of salivary glands from pancreatic glucagon [13]. These observations have been explained by considering the salivary glands IRG as aggregates of glucagon molecules [13].

Since we used the acid-ethanol extraction procedure rather than the acid-saline method preferred by most other authors we feel that discrepancies in results may be explained on the basis of different methodological approaches. Using acid-ethanol method we extracted a IRG material identical to crystalline pancreatic glucagon by the following criteria: a) immunological similarity as demonstrated by the parallelism of the dilution curves and $b$ ) indistinguishable ability to compete with ${ }^{125}$ I-glucagon for binding to rat liver membranes. In addition, after fractionation of the acid-ethanol extracts on P-30 columns or gel electrophoresis, an immunoreactive peak of 3500 daltons was always obtained. On the other hand, our results showing active incorporation of radioactive tryptophan into a 3500 daltons polypeptide reacting with a $\mathrm{C}$-terminal glucagon antiserum, are in strong support of active synthesis of the hormone by the human salivary glands. This finding was reinforced by the fact that some well known stimuli of pancreatic glucagon secretion were similarly active in promoting extrapancreactic glucagon release.

Although extrapancreatic glucagon seems to be less abundant in man than in rodents and dogs, human salivary glands and gastrointestinal mucosa could contribute to the circulating levels of glucagon. In agreement with this statement, several authors [23-26] have reported normal plasma glucagon concentrations in patients after surgical removal of pancreas and/or stomach. However other investigators have found in the same kind of patients undetectable glucagon values [27] or the absence of the true glucagon immunoreactive component [24]. Several explanations may be offered to these apparent discrepancies. First, extrapancreatic A cells are very sensitive to inhibition by insulin [8], which could be accounted for some of the cited reports $[23,27]$ especially in the patients that received insulin injections the evening before evaluation. Also the half life of the different glucagon immunoreactive forms should be considered. The half life of true glucagon is 3 minutes and that for the 9000 component is 16 minutes [28]. Furthermore both components of 65000 and 2000 daltons which have been identified in pancreactectomised patients, are not modified after somatostatin and glucose infusion indicating a longer disappearance time [29]. Otherwise, the significant dilution factor introduced by the chromatographic fractionation of plasma makes a true estimation of the different IRG components difficult when they are present in low concentrations.
The location of glucagon in salivary glands is not unique: other hormones found there include epidermal growth factor [30], nerve growth factor [31] and probably gastrin [32].

Finally, more information is needed regarding the role of glucagon from human salivary glands and its contribution to the glucagonaemia of healthy and diabetic individuals. Thus, salivary glands extracts have a diabetogenic effect [33] and the removal of these glands ameliorates the diabetic manifestations [34]. On the other hand, Dunbar et al. [10] have suggested that salivary glucagon may be a part of the entero-insular axis and participate in the hormonal response to food intake.

Acknowledgements. We gratefully acknowledge the generous collaboration of Dr. Francisco Diaz-Gonzalez and Dr. M. SerranoRios; and the valuable technical assistance of Mrs. Maria Friend.

This work was supported by grants from the Fundación Rodriguez Pascual and the Comisión Asesora para el Desarrollo de la Investigación.

\section{References}

1. Sasaki H, Rubalcava B, Baetens D, Blazquez E, Srikant CB, Orci L, Unger RH (1975) Identification of glucagon in the gastrointestinal tract. J Clin Invest 56: 135-145

2. Morita S, Doi K, Yip CC, Vranic M (1976) Measurement and partial characterization of immunoreactive glucagon in gastrointestinal tissues of dogs. Diabetes 25: 1018-1025

3. Sasagawa T, Kobayashi S, Fujita T (1973) Electron microscopy of human GEP endocrine cells. In: Fujita $T$ (ed) Gastroentero pancreatic endocrine system. Igaku Shoin, Tokyo, p $17-38$

4. Muñoz-Barragan L, Rufener C, Srikant CB, Dobbs RE, Shanon Jr WA, Baetens D, Unger RH (1977) Immunocytochemical evidence for glucagon-containing cells in the human stomach. Horm Metab Res 9: 37-39

5. Cavallero C, Solcia E, Vasallo G, Capella C, Bussolati G (1970) Cytology, cytochemistry and ultrastructure of glucagonsecreting cells. Acta Isotopica 10: 1961-1969

6. Baetens E, Rufener C, Srikant CB, Dobbs RE, Unger RH, Orci L (1976) Identification of glucagon-producing cells (Acells) in dog gastric mucosa. J Cell Biol 69: 455-464

7. Muñoz-Barragan L, Blazquez E, Patton GS, Dobbs RE, Unger RH (1976) Gastric A-cell function in normal dogs. Am J Physiol 231: 1057-1061

8. Blazquez E, Muñoz-Barragan L, Patton GS, Orci L, Dobbs RE, Unger RH (1976) Gastric A-cell function in insulin-deprived depancreatized dogs. Endocrinology 99: 1182-1188

9. Blazquez E, Muñoz-Barragan L, Patton GS, Dobbs RE, Unger RH (1977) Demonstration of gastric glucagon hypersecretion of insulin-deprived alloxan-diabetic dogs. J Lab Clin Med 89: $971-977$

10. Dunbar JC, Silverman H, Kirman E, Fòa PP (1977) Role of the submaxillary gland and of the kidney in the hyperglucagonaemia of eviscerated rats. In: Fòa PP, Bajaj JS, Fòa NL (eds) Glucagon: Its role in physiology and clinical medicine. Springer, Berlin Heidelberg New York, p 157-166

11. Silverman H, Dunbar JC (1974) The submaxillary gland as a possible source of glucagon. Bull Sinai Hosp Detroit 22: 192-193 
12. Lawrence AM, Kirstein L, Hojvat S, Rubin L, Paloyan V (1975) Salivary gland glucagon: a potent extrapancreatic hyperglycemic factor. Clin Res 23: $563 \mathrm{~A}$

13. Bathena SJ, Smith SS, Voyles NR, Penhos JC, Recant L (1977) Studies on submaxillary gland immunoreactive glucagon. Biochem Biophys Res Commun 74: 1574-1581

14. Lawrence AM, Tan S, Hojvat S, Kirstein L, Mitton J (1977) Salivary gland hyperglycaemic factor: an extrapancreatic source of glucagon-like material. Science 195: 70-72

15. Kenny AJ (1955) Extractable glucagon of the human pancreas. J Clin Endocrinol Metab 15: 1089-1105

16. Faloona GR, Unger RH (1974) Glucagon. In: Jaffe BM, Behrman HR (eds) Methods of hormone radioimmunoassay. Academic Press, New York, p 317-330

17. Davis BJ (1964) Disc electrophoresis. U. Method and application to human serum proteins. Ann NY Acad Sci 121: 404-427

18. Chrambach A, Reisfeld RA, Wyckoff M, Zaccari JA (1967) A procedure for rapid and sensitive staining of protein fractionated by polyacrylamide gel electrophoresis. Anal Biochem 20: $150-154$

19. Neville DM Jr (1968) Isolation of an organ specific protein antigen from cell-surface membrane of rat liver. Biochim Biophys Acta 154: 540-552

20. Avruch J, Wallach DFH (1971) Preparation and properties of plasma membranes and endoplasmic recticulum fragments from isolated rat fat cells. Biochim Biophys Acta 233: 334-347

21. Nottey JJ, Rosselin G (1971) Monoiodoglucagon: preparation isolement, identification, contrôle radio-immunologique. CR Acad Sci [D] (Paris) 273: 2118-2121

22. Lowry DH, Rosebrough NJ, Farr AL, Randall RJ (1951) Protein measurement with the Folin phenol reagent. J Biol Chem 193: 265-275

23. Müller WA, Brennan MF, Tan MH, Aoki TT (1974) Studies of glucagon secretion in pancreatectomized patients. Diabetes 23: $512-516$

24. Villanueva ML, Hedo VA, Marco J (1976) Plasma glucagon immunoreactivity in a totally pancreactectomized patient. Diabetologia 12: 613-616
25. Palmer JP, Werner PL, Benson JW, Ensinck JW (1976) Immunoreactive glucagon responses to arginine in three pancreatectomized humans. Metabolism 25: 1483-1485

26. Miyata M, Yamamoto Y, Yamaguchi M (1976) Plasma glucagon after total resection of the pancreas in man. Proc Soc Exp Biol Med 152: 540-543

27. Barnes AJ, Bloom SR (1976) Pancreatectomized man: a model for diabetes without glucagon. Lancet I: 219-221

28. Valverde I, Villanueva ML (1975) Heterogeneity of plasma immunoreactive glucagon. Metabolism 25 (Suppl 1): 1393-1395

29. Valverde I, Dobbs R, Unger RH (1975) Heterogeneity of plasma glucagon immunoreactivity in normal, depancreatized and alloxan-diabetic dogs. Metabolism 24: 1021-1028

30. Starkey RH, Cohen S, Orth DN (1975) Epidermal growth factor: Identification of a new hormone in human urine. Science 189: 800-802

31. Frazzier WA, Angeletti RH, Bradshaw RA (1972) Nerve growth factor and insulin. Science 176: 482-488

32. Takevchi T, Takemoto T, Tani T, Miwa T (1973) Gastrin-like immunoreactivity in salivary gland and saliva. Lancet II: 920

33. Pisanty J, Dieck MN, Garza ML, Gomez MF (1975) Diabetogenic effect of submaxillary gland implantation and submaxillary extract injection in dogs and mice. IRCS Med Sci 3: 521

34. Godlowski ZZ, Gazda M, Withers BT (1971) Ablation of salivary glands as an initial step in the management of selected forms of diabetes mellitus. Laryngoscope 81: 1337-1358

Received: February 28, 1979,

and in revised form: February 22, 1980

Dr. Enrique Blázquez

Instituto G. Marañón

Velazquez, 144

Madrid-6

Spain 